\title{
Investigating mechanical properties of hot mix asphalt containing iron ore flotation
}

\section{tailing}

\author{
Análise do comportamento mecânico de uma mistura asfáltica contendo rejeito de flotação de \\ minério de ferro
}

Análisis del comportamiento mecánico de una mezcla asfáltica conteniendo relaves de flotación de mineral de hierro

\begin{abstract}
Studies involving the use of iron ore tailings from the beneficiation process in different market niches are increasingly necessary due to the large environmental damage caused by their disposal in dams, since they are waste generated in high volumes and which have low economic value for mining companies The main purpose of this study was to investigate mechanical properties of hot mix asphalt mixture containing iron ore flotation tailing. For this, a mixture containing iron ore flotation tailing and a control mixture with natural aggregates and stone dust were prepared according to the Marshall methodology and tests of stability and flow, indirect tensile strength, resilient modulus, fatigue test and dynamic creep tests were conducted. Results show that the mixture with iron ore flotation tailing had performed technically appropriate, due to the similarity of mechanical properties of the control mixture. Therefore, the results obtained revealed that the iron ore flotation tailing presented technical characteristics appropriate to its use incorporated into hot mix asphalt. In addition, their use as an alternative material in asphalt pavements can generate environmental benefits by reducing the volume of material deposition in tailings landfills and exploration areas for mineral aggregate mining.
\end{abstract}

Keywords: Pavements; Asphalt mixtures; Iron ore flotation tailings.

\section{Resumo}

Estudos envolvendo a utilização de rejeito de flotação resultante do processo de beneficiamento do minério de ferro, em diferentes nichos de mercado, se mostram cada vez mais necessários diante do grande passivo ambiental causado pela sua disposição em aterros, uma vez que se tratam de resíduos gerados em grandes volumes e que apresentam baixo valor econômico para as empresas mineradoras. O objetivo desse trabalho foi analisar o comportamento 
mecânico de uma mistura asfáltica densa, com rejeito de flotação de minério de ferro em substituição ao fíler de agregado mineral, em comparação ao desempenho de uma mistura composta somente por agregados naturais. Para isso, as misturas foram dosadas, segundo a metodologia Marshall, e realizados ensaios de estabilidade e fluência, resistência a tração, módulo de resiliência, creep dinâmico e vida de fadiga. Os resultados obtidos nesta pesquisa revelaram que o rejeito de flotação de minério de ferro apresentou características técnicas adequadas ao seu aproveitamento, como material fino, a ser incorporado a misturas asfálticas densas. Além disso, o seu emprego como material alternativo em revestimentos asfálticos pode gerar benefícios ambientais, reduzindo-se o volume de material descartado em barragens de rejeitos e a redução de áreas de exploração de jazidas para extração de agregados minerais.

Palavras-chave: Pavimentos; Misturas asfálticas; Rejeito de flotação de minério de ferro.

\section{Resumen}

Los estudios con relaves de flotación resultantes del proceso de beneficio del mineral de hierro, en diferentes nichos de mercado, son cada vez más necesarios ante el gran pasivo ambiental que genera su disposición en rellenos sanitarios, ya que son residuos generados en grandes volúmenes y de bajo valor económico para la minerías compañías. El objetivo de este trabajo fue analizar el comportamiento mecánico de una mezcla asfáltica densa, con relaves de flotación de mineral de hierro en sustitución del relleno de agregados minerales, en comparación con el comportamiento de una mezcla compuesta únicamente por agregados naturales. Para ello, se dosificaron las mezclas, según la metodología Marshall, y se realizaron ensayos de estabilidad y fluencia, resistencia a la tracción, módulo de resiliencia, fluencia dinámica y vida a fatiga. Los resultados obtenidos en esta investigación revelaron que los relaves de flotación de mineral de hierro presentaban características técnicas adecuadas para su uso, como un material fino para ser incorporado en mezclas asfálticas densas. Además, su uso como material alternativo en revestimientos asfálticos puede generar beneficios ambientales, reduciendo el volumen de material descartado en presas de relaves y reduciendo las áreas de exploración de depósitos para la extracción de agregados minerales.

Palabras clave: Pavimentos de carreteras; Mezclas asfálticas; Relaves de flotación de mineral de hierro.

\section{Introduction}

Mining is one essential activity for the global economy, as it supplies raw material to the productive chains of several sectors. Minerals like iron are vital components of any national economy, but due to the rapid industrial process, a great deterioration in the quality of environment can occur (Sharath, et al., 2018). This implies in the generation and deposition of tailings, in dams and containment dykes, which cause damage to the natural ecosystem by producing various types of pollution like land degradation, air pollution, dust pollution etc. (Gayana \& Chandar, 2018). With the increase in the sector's productivity, there is also growth in the generation of tailings, which demands larger areas for deposition.

Iron ore tailings (IOT) are a form of solid waste produced during the beneficiation process of iron ore concentrate. Among all kinds of mining solid waste, IOTs are one of the most common solid wastes in the world due to their high output and low utilization ratio (Tang, et al., 2019; Sun, et al., 2011). For this reason, the production of tailings has been getting much attention of companies around the world, to minimize environmental impacts and costs associated with the processes of deposition, with the use of mine tailings in civil engineering construction (Kuranchie, et. al., 2014). This practice can help reduce the emission of greenhouse gases, by avoiding the mining of virgin engineering materials, providing cheaper alternative materials for building and construction, and for natural resource conservation (Chen, et al., 2011).

The IOT are generated by the ore beneficiation process and the well-now process are flotation separation and magnetic separation. The flotation process consists of a surface physical-chemical process, used in the separation of minerals, which gives rise to the formation of an aggregate, mineral particle and air bubble, which, in a watery environment, floats in the form of foam, while the magnetic concentration process consists of the tailings from the processing of waste introducing dry treatment, without using water to process it (Filippov, et al., 2014).

IOT can be used to make products like ceramic (Das, et al., 2000; Das, et al., 2012), cementitious composites (Huang, et al., 2013), epoxy composites (Adedayo \& Onitiri, 2010), bricks, cement, concrete building materials for civil construction and underground backfill mining materials (Bing, et al., 2018).

Roads are built using different materials like gravel, sand, aggregates, asphalt binder, cement, etc. There has been 
constant research to replace or substitute the materials by other materials for better pavement of roads. In the process, the waste produced from various sources can be an effective replacement, as the waste will be available at free of cost or with minimum price and on the other hand, handling and disposal of waste also minimizes (Gayana \& Chandar, 2018). As a measure for conserving natural resources and environmental pollution, the use of waste materials in highway construction has been considered in recent years, and different types of waste materials have proved applicable as a replacement for virgin materials (Taherkhani \& Arshadi, 2019).

Applying iron tailings to road engineering can consume a lot of iron tailings and reduce the cost of road engineering. China's iron tailings as road building materials are still in initial study phase (Bing, et al., 2018). The use of waste materials in asphalt pavements is the most effective way for decreasing the exploitation of natural resources and environmental pollution (Arabani, et al., 2017).

A few studies have utilized IOT with material in asphalt pavements. Bastos, et al. (2016) evaluate the viability of iron ore tailings from tailing dams as an alternative material for road infrastructure. The iron ore tailings were characterized according to their chemical, mineralogical, environmental, and physical properties. Subsequently, the tailings were chemically stabilized using cement, lime, or steelmaking slag as binder. The tailing-cement, tailing-lime, and tailing-slag mixtures studied consisted of 1,2,5, and 10\% binder content, each. The characterization methodology included chemical and mineralogical analysis through X-ray fluorescence and diffraction; environmental analysis with leaching and dissolution tests; evaluation of compaction curves; California bearing ratio (CBR) tests and expansion assessment; compressive strength, with curing in moisture chamber or at open air; water absorption; and evaluation of durability of the mixtures. The cement was the most efficient stabilizer among the studied binders.

Lara, et al. (2018) studied the mechanical behavior of a lateritic soil with addition of iron ore flotation tailings for application as subgrade reinforcement material and subbase of road pavements, considering the substitution of $0 \%, 25 \%, 50 \%$ and $75 \%$ of the IOT on in the mixtures with the soil. The results showed an increase in soil CBR values with addition of IOT, and a decrease in the expansion. Results of cyclic triaxial tests confirmed the capability of the resilient composite model applied to the mixtures, which enable them to be used as pavement layers, especially as subgrade reinforcement material and subbase material. Grasse, et al. (2019) studied the effect of the addition of the iron ore flotation tailings on a lateritic soil chemically stabilized with $2 \%, 4 \%$ and $6 \%$ of lime, for application in base and subbase layers of road pavements. The results showed an increase in CBR values of the soil-lime mixtures with the addition of iron ore flotation tailing, and the decrease of the expansion. It was concluded that the IOT addition caused positive changes in the values of unconfined compression strength of the soil-lime mixtures.

Apaza, et al. (2018) studied the physical and mechanical characterization of cold-mix microsurfacing treatment, considering the substitution of $0 \%, 10 \%, 15 \%$ and $20 \%$ of the iron waste as small aggregate. It was conducted the Wet Stripping Test - WST and the Modified Cohesion Test - MCT to analyze the compatibility of materials. The mechanical behavior of cold-mix microsurfacing test specimens containing aggregates of the iron residue showed to perform similarly to the usual aggregates, until $20 \%$ of substitution, indicating that it is a material with promising use in this type of technique of paving.

A review of the literature on IOT as material in asphalt pavements shows that the properties of these mixtures, especially hot mix asphalt mixtures, have not been fully investigated. Therefore, in this laboratory investigation, the impacts of utilizing IOT, in some engineering properties of hot mix asphalt (HMA) were investigated.

\section{Materials}

The materials utilized in this research were asphalt binder, aggregates, and iron ore flotation tailing (IOT). A asphalt 
binder of 50/70 penetration grade from Gabriel Passos Refinery (REGAP) in Brazil was used to produce the specimens in this study. Table 1 shows a summary of the asphalt binder properties.

Table 1. Conventional rheological properties of the asphalt binder used in this study.

\begin{tabular}{lccc}
\hline \multicolumn{1}{c}{ Test } & Standard & Results & Specification limits \\
\hline Penetration Index $\left(25^{\circ} ; 0.1 \mathrm{~mm}\right)$ & ASTM D5 & 50 & 50 to 70 \\
Softening point $\left({ }^{\circ} \mathrm{C}\right)$ & ASTM D36 & 50 & $\geq 46$ \\
Flash point $\left({ }^{\circ} \mathrm{C}\right)$ & ASTM D92 & 362 & $\geq 235$ \\
Viscosity at $135^{\circ} \mathrm{C}(\mathrm{Pas})$ & ASTM D4402 & 0.302 & $\geq 0.274$ \\
Ductility $\left(25^{\circ} ; \mathrm{cm}\right)$ & ASTM D113 & $>150$ & $\geq 60$ \\
Specific gravity $\left(25^{\circ} ; \mathrm{g} / \mathrm{cm} 3\right)$ & ASTM D70 & 1.011 & N/A \\
\hline
\end{tabular}

Source: Authors (2021).

In this study, gneiss aggregates from Itabira region, Minas Gerais State, were collected and used in asphalt mixtures. Table 2 presents the properties of the coarse, fine, and filler fractions of aggregates and filler fractions of the IOT. IOT samples were collected at the output of the flotation duct of the Cauê mine from Itabira, Brazil.

Table 2. Aggregates and filler IOT properties.

\begin{tabular}{|c|c|c|c|c|c|c|}
\hline Properties Materials & 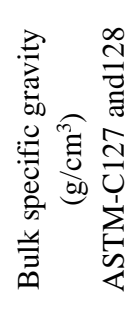 & 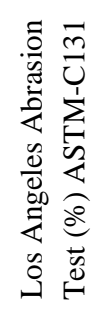 & 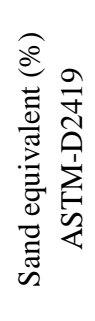 & 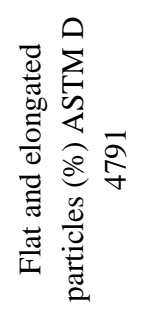 & 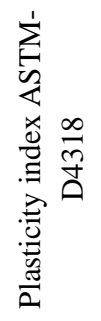 & 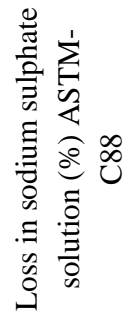 \\
\hline Coarse aggregates & 2.660 & 42 & - & 24 & - & 1.42 \\
\hline Fine aggregates & 2.717 & - & 74 & - & NP & 3.22 \\
\hline Filler & 2.759 & - & - & - & NP & - \\
\hline Filler (IOT) & 3.160 & - & - & - & NP & - \\
\hline
\end{tabular}

Source: Authors (2021).

A dense gradation with the maximum aggregate size of $19.1 \mathrm{~mm}$ was selected based on the Brazil Asphalt Pavement Standard for asphalt mixtures, denominated C granulometric composition. Figure 1 illustrates the specification limits and gradation of the mixtures in this study. Figure 2 shows the granulometric curve of the IOT, utilized in this study. 
Figure 1. Gradation of the aggregates mixtures used in this study.

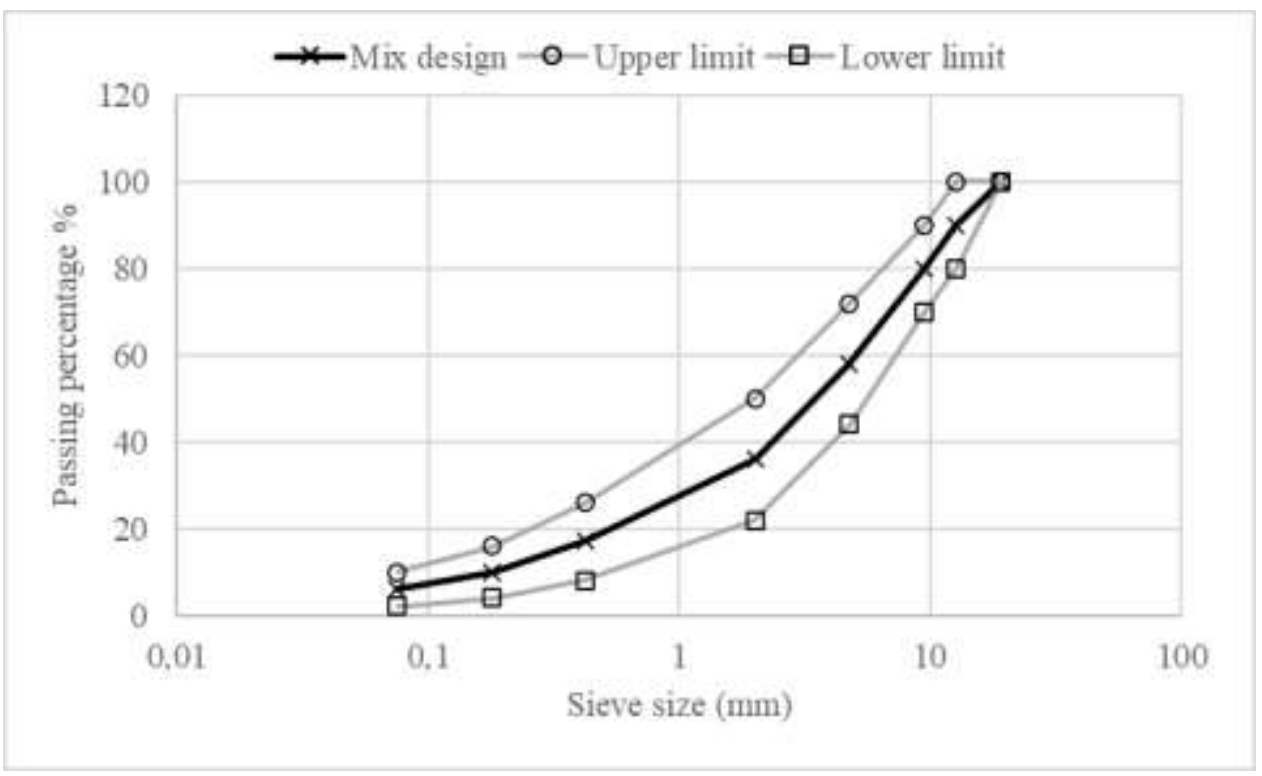

Source: Authors (2021).

As shown in Figure 1, the particle size range chosen for the mixtures is in the center of the limits of the range $\mathrm{C}$ granulometric composition.

Figure 2. IOT granulometric curve.

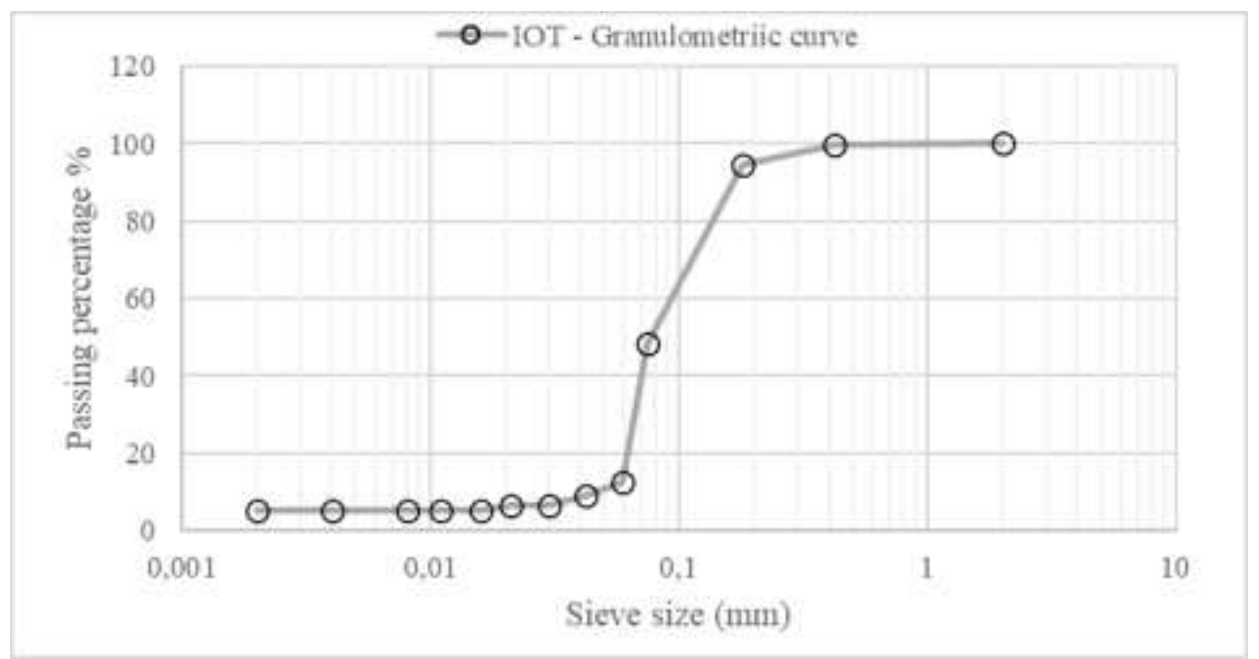

Source: Authors (2021).

According to Figure 2, the iron ore flotation tailing has more than $90 \%$ passing material in the $0.18 \mathrm{~mm}$ sieve and approximately $50 \%$ passing material in the $0.075 \mathrm{~mm}$ sieve.

Figure 3 shows the IOT used in the experiment. The mineralogical composition of the IOT was determined by X-Ray Diffraction and the results indicate that the iron ore flotation has mineralogy composed of silicates (quartz, kaolinite, talc, pyrophyllite and muscovite), iron oxide (hematite) and aluminum hydroxide (gibbsite). Additionally, particle shape and surface analysis of the IOT fillers were examined by scanning electron microscopy (SEM). As shown in Figure 4, particles had angular shapes and there is a heterogeneity in the shape and size of the particles, ranging from particle sizes between 10 to $100 \mu \mathrm{m}$. 
Figure 3. Iron ore flotation tailing used in this study.

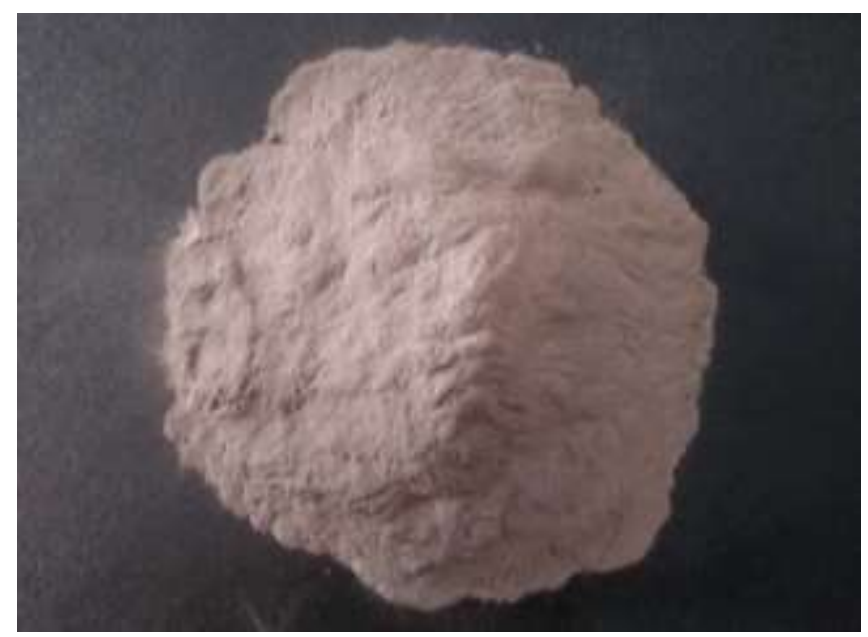

Source: Authors (2021).

Figure 4. SEM image of the IOT.

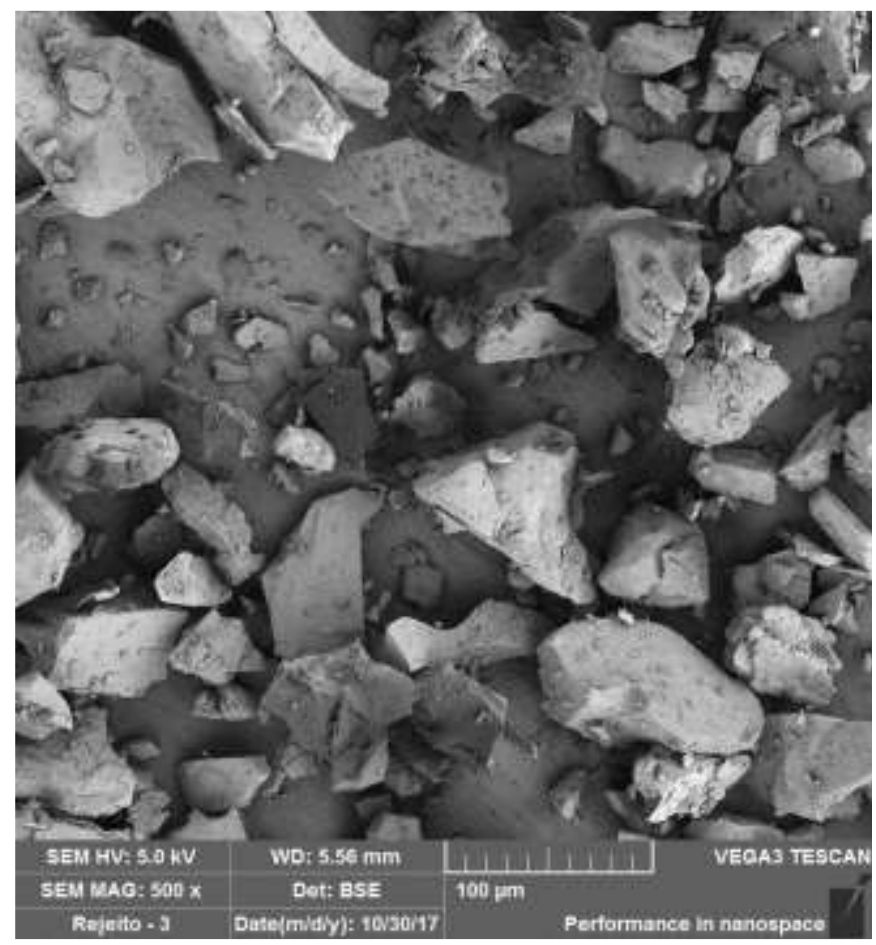

Source: Authors (2021).

\section{Method}

\subsection{Specimens preparation}

The asphalt mixtures were prepared according to ASTM D1559. The aggregates were heated to $150-160^{\circ} \mathrm{C}$ for $24 \mathrm{~h}$ before preparing HMA mixtures. Then, the asphalt binder was heated to the temperature of $145-151^{\circ} \mathrm{C}$ before being mixed with aggregates. The amount of filler for all studied mixture proportions was fixed to $6 \%$. The optimum asphalt binder contents were found to be $4.72 \%$ to the control mixture (CM) and 5.26\% to the mixture with IOT (IOTM), using the Marshall mix design method. The mixtures were compacted at $135-140^{\circ} \mathrm{C}$ by a Marshall hammer with 75 blows per side and three samples were prepared to each test. 


\subsection{Marshal Tests}

Marshall tests were conducted on the specimens according to ASTM D1559 standard method. The prepared specimens were placed in a water bath at $60^{\circ} \mathrm{C}$ for 30 min of immersion, after which they were loaded using a Marshall test set-up at the constant rate of $50.8 \mathrm{~mm} / \mathrm{min}$. The force required for breaking the specimen was measured as the Marshall stability (MS), and the diametrical deformation of the specimen at failure was measured as Marshall Flow (MF).

\subsection{Indirect Tensile Strength (ITS)}

Indirect Tensile Strength (ITS) tests were conducted according to ASTM D6931 standard method (specimens with $101.6 \mathrm{~mm}$ in diameter and $63.5 \mathrm{~mm}$ in height). Three specimens for each mixture were prepared and placed in a conditioned chamber at $25^{\circ} \mathrm{C}$ per 4 hours, after which they were loaded using a Marshall test set-up at the constant rate of $50.8 \mathrm{~mm} / \mathrm{min}$. The required force for breaking the specimen was measured and ITS was calculated using the Equation (1),

$$
I T S=\frac{2000 P}{\pi+D}
$$

where ITS is the indirect tensile strength in $\mathrm{kPa}, \mathrm{P}$ is the maximum applied load for breaking the specimen in $\mathrm{N}, \mathrm{D}$ is the specimen diameter in $\mathrm{mm}$, and $\mathrm{t}$ is the specimen height immediately before test in $\mathrm{mm}$.

Indirect tensile strength is considered as the potential test method for determining the tensile properties of asphalt mixture which can be further related to rutting and cracking properties of asphalt mixture (Moghaddam, et al., 2014). The values of ITS may be used to evaluate the relative quality of asphalt mixtures in conjunction with another laboratory mix design testing and for estimating the potential for rutting or cracking. Tensile strength is one of the main properties of asphaltic mixtures and is related to the strength against cracking and permanent deformation. A mixture with a higher tensile strength is more resistant against cracking and permanent deformation (Esfahani \& Jahromi, 2020; Taherkhani \& Arshadi, 2019).

\subsection{Resilient Modulus (Mr)}

The Mr test was conducted using a modular electro-mechanically operated asphalt tester apparatus according to ASTM D4123. A haversine load pulse was applied at a frequency of $1 \mathrm{~Hz}$, including $0.1 \mathrm{~s}$ loading and $0.9 \mathrm{~s}$ rest period. The Poisson's ratio was assumed as 0.35 . Based on the standard method, depending upon the loading frequency, mix type, and testing condition, 50-200 loading repetitions might be needed. The minimum value must be determined so that the resilient deformations become stable. Based on the laboratory observations, 150 load repetitions were selected. In this research, to measure the resilient modulus the specimens were tested at three temperatures of 10,25 and $40^{\circ} \mathrm{C}$. Three specimens were fabricated for each test. For an applied dynamic load of $\mathrm{P}$ in which the resulting horizontal dynamic deformations are measured, the total Mr value cam be calculated using Equation (2),

$$
M_{r}=\frac{P(v+0.27)}{t \Delta H}
$$

where $\mathrm{Mr}$ is the resilient modulus (MPa), $\mathrm{P}$ is the repeated load $(\mathrm{N}), \mathrm{t}$ is the sample's thickness $(\mathrm{mm}), \Delta \mathrm{H}$ is the recoverable horizontal deformation $(\mathrm{mm})$ and $v$ is the resilient Poisson ratio.

The values of resilient modulus can be used to evaluate the relative quality of materials as well as to generate input for pavement design or pavement evaluation and analysis. Resilient modulus, which describes the elastic and plastic behavior of a mixture against loading, shows a pavement's response in terms of dynamic stresses and the corresponding strains. Since this parameter is a good indicator of real mixture performance, many have used it in pavement design in recent decades (Esfahani \& Jahromi, 2020). 


\subsection{Creep Dynamic Test}

In this study, dynamic creep tests were conducted on cylindrical specimens $(101.6 \mathrm{~mm}$ in diameter and $63.5 \mathrm{~mm}$ in height). During the test dynamic compressive loadings with the peak of $200 \mathrm{kPa}$ were applied. The loading time was $0.1 \mathrm{~s}$ and rest period of $0.9 \mathrm{~s}$ was designated for this study. The amounts of cumulative permanent strains were recorded during applying 3600 loading cycles. The cumulative axial strain was calculated according to Equation (3),

$$
\varepsilon=\frac{\hbar}{H_{0}}
$$

where $\varepsilon$ is the cumulative axial strain, $h$ is the axial deformation and $\mathrm{H}_{0}$ is the initial height of specimen. Dynamic creep test was conducted at $40{ }^{\circ} \mathrm{C}$, and to reach a uniform mixture temperature all the specimens were placed in controlled temperature chamber for at least $4 \mathrm{~h}$.

Creep modulus is the most important output of the dynamic creep test. The value of creep modulus is an additional indication of the resistance to permanent axial deformation and for bituminous specimens which are basically obtained from the ratio of applied stress (200 kPa) to the cumulative compressive strain at a defined temperature and time of loading. Mixtures with a lower creep modulus are known to undergo higher deformation (Nejad, et al., 2014). The creep modulus (S) was calculated according to Equation (4),

$$
S=\frac{\sigma}{\varepsilon}
$$

where $\sigma$ is the applied stress and $\varepsilon$ is the axial strain.

\subsection{Fatigue Test}

One of the important parameters to be considered in pavement design is the traffic and the repeated load applications by the moving vehicles. Excessive deflection of pavement under moving load is considered as one of the prime mechanisms of pavement failure. The dynamic stiffness of the pavement mix plays an important role in determining the fracture characteristics and fatigue behavior of the pavement (Chandra, et al., 2002). Fatigue tests are carried out with two models: controlled strain and controlled stress. In the controlled strain mode, the strain is kept constant by decreasing the stress during the test, whereas in the controlled stress mode, the stress is kept constant, which increases the strain during the test (Arabani, et al., 2010).

In this study the tests were conducted under controlled stress conditions. Fatigue tests were conducted at 10, 20, 30 and $40 \%$ of ultimate compressive indirect tensile strength. Three specimens (101.6 $\mathrm{mm}$ in diameter and $63.5 \mathrm{~mm}$ in height) for each mixture and each level of indirect tensile strength were prepared and placed in a conditioned chamber at $25^{\circ} \mathrm{C}$ for 4 hours (Figure 5). The loading time was $0.1 \mathrm{~s}$, and $0.9 \mathrm{~s}$ was considered for rest period. Failure of mixes occurred when the specimen collapsed. 
Figure 5. Electro-mechanically asphalt tester apparatus for fatigue tests.

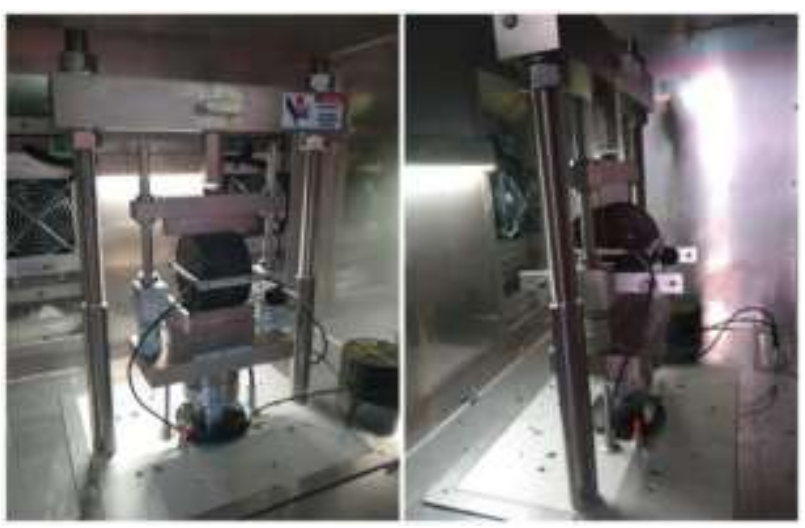

Source: Authors (2021).

A Linear regression analysis of the fatigue tests results was used to determine fatigue functions for the asphalt mixtures using the Equation (4),

$$
N_{f}=a\left(\frac{1}{\varepsilon_{0}}\right)^{b}
$$

where $\mathrm{N}_{\mathrm{f}}$ is the number of cycles to failure of the specimen, $\varepsilon_{0}$ is the initial tensile strain (micro-strain), and a and $b$ are experimentally determined coefficients.

\section{Results and Discussion}

\subsection{Marshal Stability ad Flow Tests}

Table 3 presents the Marshall Stability and flow results for the CM and IOTM mixtures. The values represent the average of the results for three replicates specimens of each mixture. The results show that the mixtures containing IOT have a higher stability than the CM mixture. As shown in the Table 3, Marshall stability of the IOTM specimens increased 5.3\% and the flow decreased $6.8 \%$. High flow values generally indicate a plastic mix that will experience accelerate permanent deformation under traffic loads.

Table 3. Marshall Stability, Flow and MQ for all mixtures.

\begin{tabular}{lccc}
\hline Mixture ID & Marshall stability $(\mathrm{kN})$ & Marshall flow $(\mathrm{mm})$ & $\begin{array}{c}\text { MQ } \\
(\mathrm{kN} / \mathrm{mm})\end{array}$ \\
\hline CM & 15.15 & 2.94 & 5.15 \\
IOTM & 15.96 & 2.74 & 5.82 \\
\hline
\end{tabular}

Source: Authors (2021).

The relationship between MQ (Marshall Stability divided by Flow) and type of mixture is provided in Table 3. As shown in the Table 3, MQ of IOTM specimens increased 13.03\%. According to Arabani, et al. (2010) and Nejad, et al. (2014) Marshall quotient (MQ) is defined as the ratio of stability $(\mathrm{kN})$ to flow $(\mathrm{mm})$ and a higher value of stability divided by flow indicated a stiffer mixture and, hence, the mixture was likely to be more resistant to permanent deformation.

\subsection{Indirect Tensile Strength (IDT)}

Table 4 presents IDT results for the CM and IOTM mixtures. The values represent the average of results for three replicates specimens. The results show that the mixtures containing IOT have a similar value that the obtained for CM mixture. 
According to the Brazil National Department of Transport Infrastructure Highway Standard Code (DNIT 031-2006), minimum IDT must be $0.65 \mathrm{MPa}$ in hot mix asphalt.

Table 4. Indirect Tensile Strength results.

\begin{tabular}{lc}
\hline Mixture ID & IDT (MPa) \\
\hline CM & 1.431 \\
IOTM & 1.434 \\
\hline
\end{tabular}

Source: Authors (2021).

\subsection{Resilient Modulus (Mr)}

Figure 6 illustrates the resilient modulus variation versus temperature for CM and IOTM specimens. Each specimen was prepared with optimum binder content and the results presented in Figure 6 are the average of three replicates, for each temperature. The results show that as the temperature increases, the resilient modulus of the asphalt mixtures decreases. This phenomenon occurs due the change in the viscosity of bitumen with respect to temperature (Meor \& Teoh, 2008).

For the three temperatures tested, the IOTM asphalt mixture presented lower values of resilient modulus compared with those results for the $\mathrm{CM}$ mixtures. However, for the temperature of $10^{\circ} \mathrm{C}$ the resilient modulus of the IOTM was lower by about $14.5 \%$ in comparison to the control mixture. For temperatures of $25{ }^{\circ} \mathrm{C}$ and $40{ }^{\circ} \mathrm{C}$ the reductions were $2.82 \%$ and $6.95 \%$, respectively.

Figure 6. Resilient modulus versus temperature.

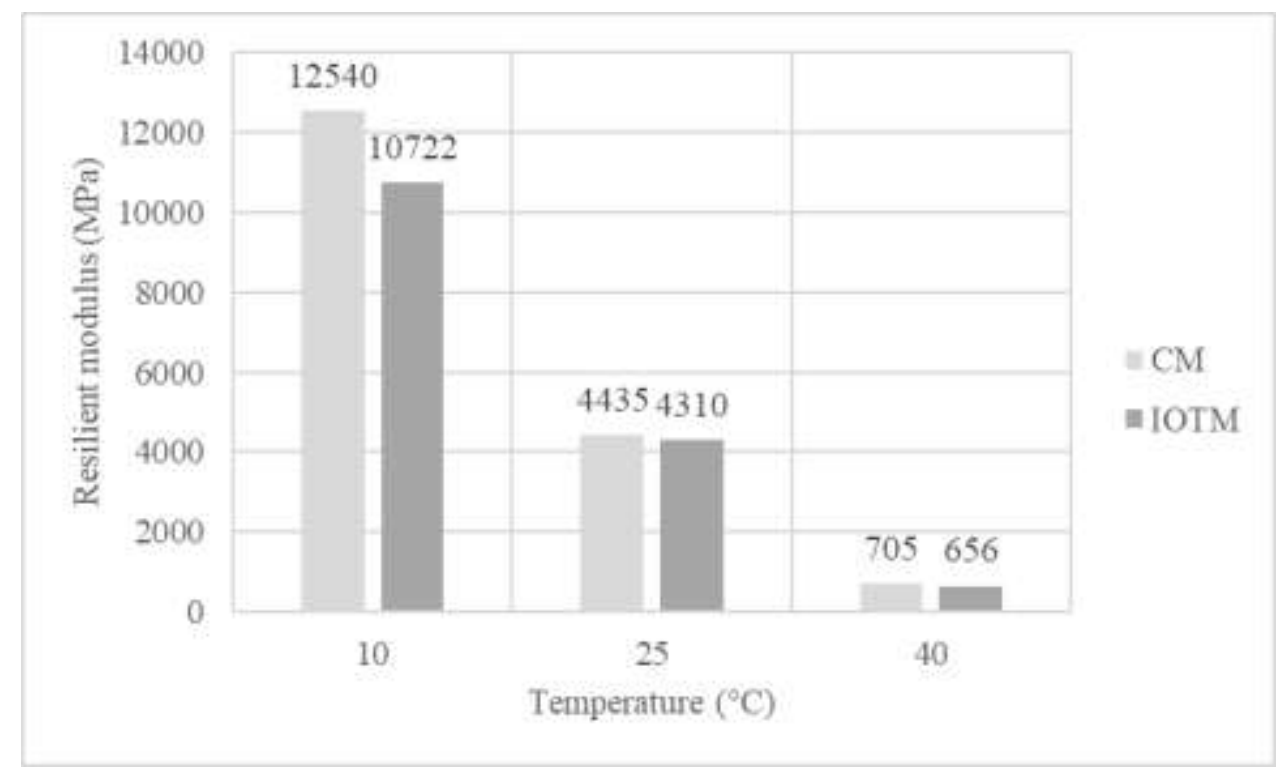

Source: Authors (2021).

\subsection{Creep Dynamic Test}

Creep modulus and cumulative axial strain values of control and IOT mixtures are given in Figure 7. The values are the average of three tests results by each mixture. In the CM specimens, the creep modulus was lower than the results for the IOTM, while the cumulative axial strain was higher.

To the same loading level and test conditions, the IOT mixture showed less susceptibility to permanent deformation, and compared with the MQ results, the IOTM showed as a stiffer mixture and more resistant to permanent deformation. According to the correlations between traffic intensity and creep modulus, presented by Little, et al. (1993), the values found 
for the mixtures are compatible with the performance of asphalt mixtures for application in pavements subject to moderate traffic intensity.

Figure 7. Creep modulus and cumulative axial strain values of the control and modified asphalt mixture with IOT.

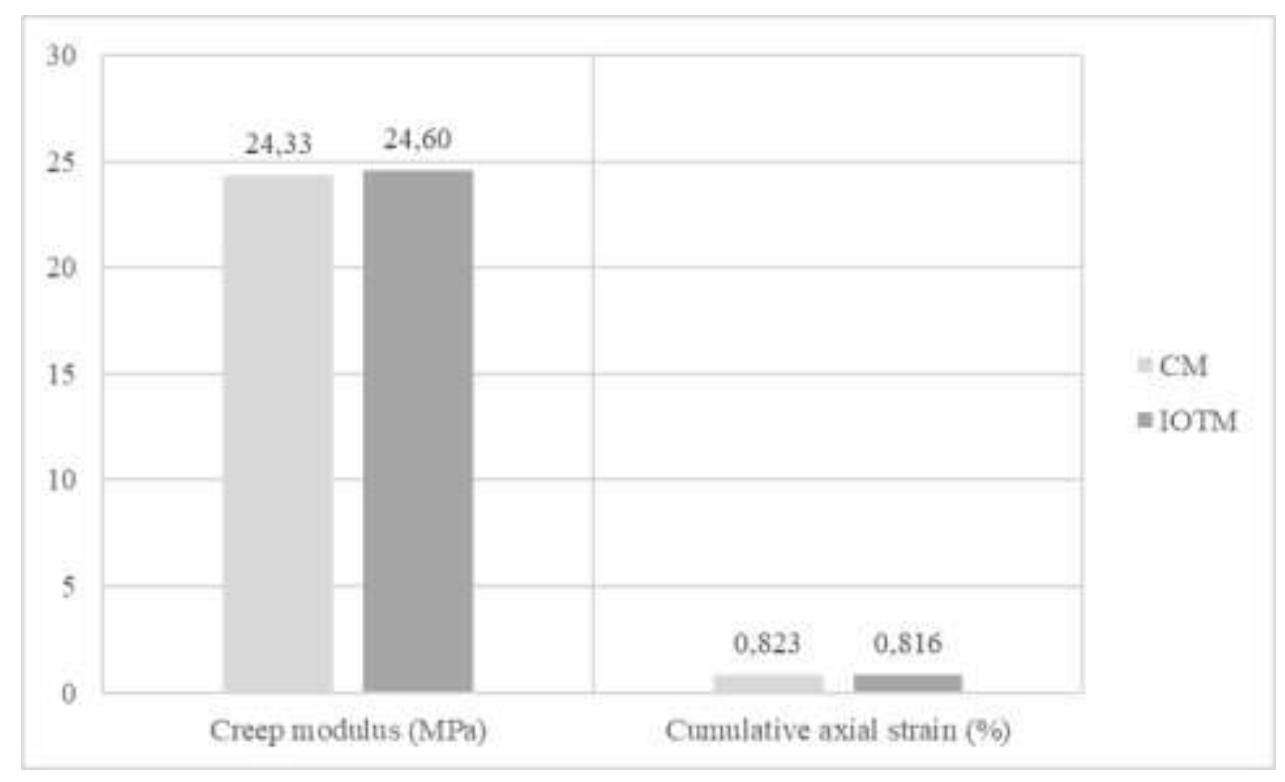

Source: Authors (2021).

\subsection{Fatigue test}

As shown in Figure 8, the fatigue prediction models for mixtures were presented according to the fatigue tests results obtained in this study. There is a linear relationship between tensile strain and fatigue life in the logarithm scale. The fatigue models for mixtures and R2 values are presented in Table 5. Although the models show similar behavior, for the initial application stages of load cycles the mixture with the addition of IOT showed higher values of strains, and for the final stages the same mixture showed lower values, when compared with the CM.

Figure 8. Comparison of the curves for the fatigue life of CM and IOT mixtures.

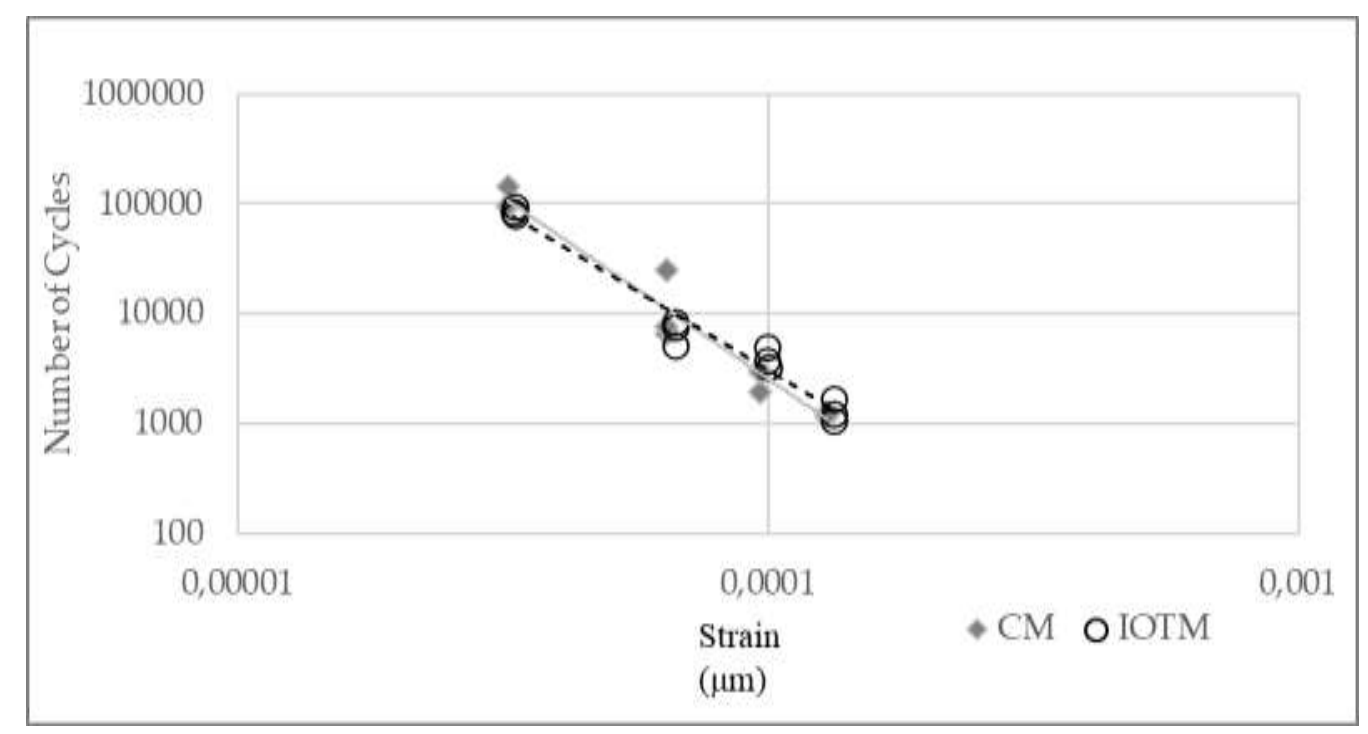

Source: Authors (2021). 
Table 5. Fatigue prediction models.

\begin{tabular}{lcc}
\hline Mixture ID & Fatigue Model & $\mathrm{R}^{2}$ \\
\hline $\mathrm{CM}$ & $N=2 \times 10^{-10} \times\left(\frac{1}{\varepsilon}\right)^{3,306}$ & 0.964 \\
IOTM & $N=7 \times 10^{-9} \times\left(\frac{1}{\varepsilon}\right)^{2,908}$ & 0.967 \\
\hline
\end{tabular}

Source: Authors (2021).

$\mathrm{R}^{2}$ value determine how closely the data conform to a linear relationship. The higher the $\mathrm{R}^{2}$, the better the model fits the data. As presented in Table 5 the $\mathrm{R}^{2}$ values to the mixtures fit to the data and indicates that the models explain all the variability of the response data around its mean.

\section{Conclusions}

In this research, the impacts of utilizing IOT in some engineering properties of hot mix asphalt (HMA) were investigated. Based on the results, the following conclusions can be derived:

- When IOT was used in the mixture, Marshall Stability average value of the specimens increased, and flow decreased.

- IOT mixture had a higher value of stability divided by flow (MQ), which indicated a stiffer mixture, and the mixture was likely to be more resistant to permanent deformation.

- Although the MQ higher value obtained for the IOT mixture, the indirect tensile strength tests result in similar average values for both.

- At 10,25 and $40^{\circ} \mathrm{C}$ temperatures the highest resilient modulus values of the mixtures were obtained from the CM mixture.

- At $10^{\circ} \mathrm{C}$, the resilient modulus of bituminous mixtures with IOT exhibited lower value. This shows that a better performance can be achieved in cold region by using IOT as filler.

- According with the results of creep tests, resistance against permanent deformation of IOT asphaltic mixtures increases.

- for the initial application stages of load cycles, the mixture with IOT showed higher values of strains, and for the final stages the same mixture showed lower values, when compared with the CM.

Based on the results, as a way of conserving natural resources and reduce high accumulation of this material in the environment, the studied iron ore tailing material can be used in HMA for road construction.

As a suggestion for future work, build experimental segments in roadways with the studied mixtures to evaluate their performance under the action of vehicular traffic loads and the weather, over design time.

\section{Acknowledgments}

The authors would like to acknowledge the Federal University of Itajubá for the infrastructure support and VALE S.A. company for the financing of research. 


\section{References}

Adedayo, S. M., \& Onitiri, M. A. (2010). Tensile Properties of Iron Ore Tailings Filled Epoxy Composites. The West Indian Journal of Engineering, 35(1), 51-59.

Apaza, F. R., Guimarães, A. C. R., Sousa, M. A. S., \& Castro, C. D. (2018). Study of tilization of iron ore tailing (IOT) in cold-mix micro-surfacing treatment. Transportes, 26(2), 118-138. https://doi.org/10.14295/transportes.v26i2.1254

Arabani, M., Mirabdolazimi, S. M., \& Sasani, A. R. (2010). The effect of waste tire thread mesh on the dynamic behaviour of asphalt mixtures. Construction and Building Materials, 24(6), 1060-1068. https://doi.org/10.1016/j.conbuildmat.2009.11.011

Arabani, M., Tahami, S. A., \& Taghipoor, M. (2017). Laboratory investigation of hot mix asphalt containing waste materials. Road Materials and Pavement Design, 18(3), 713-729. https://doi.org/10.1080/14680629.2016.1189349

Bastos, L. A. C., Silva, G. C., Mendes, J. L., \& Peixoto, R. A. F. (2016). Using Iron Ore Tailings from Tailing Dams as Road Material. Journal of Materials in Civil Engineering, 28(10). https://doi.org/10.1061/(ASCE)MT.1943-5533.0001613

Bing, L., Zhongying, Z., Biao, T., Hongbo, L., Hanchi, C., \& Zhen, M. (2018). Comprehensive Utilization of Iron Tailings in China. Proceedings of IOP Conference Series: Earth and Environmental Science, 199(4), 1-4. https://doi.org/10.1088/1755-1315/199/4/042055

Chandra, S., Kumar, P., \& Feyissa, B. A. (2002). Use of Marble Dust in Road Construction. Road Materials and Pavement Design, 3(3), 317-330. https://doi.org/10.1080/14680629.2002.9689928

Chen, Y., Zhang, Y., Chen, T., Zhao, Y., \& Bao, S. (2011). Preparation of eco-friendly construction bricks from hematite tailings. Construction and Building Materials, 25(4), 2107-2111. https://doi.org/10.1016/j.conbuildmat.2010.11.025

Das, S. K., Kumar, S., \& Ramachandrarao, P. (2000). Exploitation of iron ore tailing for the development of ceramic tiles. Waste Management, 20(8), 725729. https://doi.org/10.1016/S0956-053X(00)00034-9

Das, S. K., Ghosh, J., Mandal, A. K., Singh, N, \& Gupta, S. (2012). Iron ore tailing: a waste material used in ceramic tile compositions as alternative source of raw materials. Transactions of the Indian Ceramic Society, 71(1), 21-24. http://dx.doi.org/10.1080/0371750X.2012.689507

Esfahani, M. A., \& Jahromi, M. N. (2020). Optimum parafibre length according to mechanical properties in hot mix asphalt. Road Materials and Pavement Design, 21(3), 683-700. https://doi.org/10.1080/14680629.2018.1527240

Filippov, L. O., Severov, V. V., \& Filippova, V. C. (2014). An overview of the beneficiation of iron ores via reverse cationic flotation. International Journal of Mineral Processing, 127(1), 62-69. https://doi.org/10.1016/j.minpro.2014.01.002

Gayana, B. C., \& Chandar, K. R. (2018). Sustainable use of mine waste and tailings with suitable admixture as aggregates in concrete pavements-A review. Advances in Concrete Construction, 6(3), 221-243. https://doi.org/10.12989/acc.2018.6.3.221

Grasse, B. P., Soncim, S. P., Almeida, M. A., Oliveira, C. A. S., Belotti, F. M., Cavalcante, E. H. \& Resende, L. (2019). Evaluation of the geotechnical behavior of a lateritic soil stabilized with lime and iron ore flotation tailings. In C. S. Pitombo, \& C. M. Oliveira (Eds.), Proceedings of the $33^{\circ}$ Transport Research and Teaching Congress (pp.1-12). National Transport Research and Education Association Press.

Huang, X., Ranade, R., \& Li, V. C. (2013). Feasibility study of developing green ECC using iron ore tailings powder as cement replacement. Journal of Materials in Civil Engineering, 25(7), 923-931. https://doi.org/10.1061/(ASCE)MT.1943-5533.0000674

Kuranchie, F. A., Shukla, S. K., \& Habibi, D. (2016). Utilisation of iron ore mine tailings for the production of geopolymer bricks. International Journal of Mining, Reclamation and Environment, 30(2), 92-114. https://doi.org/10.1080/17480930.2014.993834

Lara, L. D. L, Queiroz, B. G., Soncim, S. P., Almeida, M. A., Oliveira, C. A. S., Belotti, F. M., Cavalcante, E. H. \& Resende, L. (2018). Study of the geotechnical behavior of a soil with addition of iron ore flotation tailing for use in road construction. In F. J. C. Cunto, \& C. M. Oliveira (Eds.), Proceedings of the $32^{\circ}$ Transport Research and Teaching Congress (pp.1966-1977). National Transport Research and Education Association Press.

Little, D. N., Button, J. W., Youssef, H. (1993). Development of criteria to evaluate uniaxial creep data and asphalt concrete permanent deformation potential. Transportation Research Record, 1417, 49-57. http://onlinepubs.trb.org/Onlinepubs/trr/1993/1417/1417-006.pdf

Meor, O. H., \& Teoh, C. Y. (2008). Effects of temperature on resilient modulus of Dense asphalt mixtures incorporating steel slag subjected to short term oven ageing. International Journal of Civil and Environmental Engineering, 2(10), 222-226. https://doi.org/10.5281/zenodo.1070199

Moghaddam, T. B., Soltani, M., \& Karim, M. R. (2014). Experimental characterization of rutting performance of Polyethylene Terephthalate modified asphalt mixtures under static and dynamic loads. Construction and Building Materials, 65(1), 487-494. https://doi.org/10.1016/j.conbuildmat.2014.05.006

Nejad, F. M., Azarhoosh, A., Hamedi, G. H., \& Roshani, H. (2014). Rutting performance prediction of warm mix asphalt containing reclaimed asphalt pavements. Road Materials and Pavement Design, 15(1), 207-219. https://doi.org/10.1080/14680629.2013.868820

Sharath, B. P., Shivaprasad, K. N., Athikkal, M. M. \& Das, B. B. (2018). Some studies on sustainable utilization of iron ore tailing (IOT) as fine aggregates in fly ash based geopolymer mortar. Proceedings of IOP Conference Series: Materials Science and Engineering, 431(9), 1-8. https://doi.org/10.1088/1757$899 \mathrm{X} / 431 / 9 / 092010$

Sun, J. S., Dou, Y. M., Chen, Z. X., \& Yang, C. F. (2011). Experimental Study on the Performances of Cement Stabilized Iron Ore Tailing Gravel in Highway Application. Applied Mechanics and Materials, 97-98, 425-428. https://doi.org/10.4028/www.scientific.net/amm.97-98.425

Taherkhani, H., \& Arshadi, M. R. (2019). Investigating the mechanical properties of asphalt concrete containing waste polyethylene terephthalate. Road Materials and Pavement Design, 20(2), 381-398. https://doi.org/10.1080/14680629.2017.1395354

Tang, C., Li, K., Ni, W., \& Fan, D. (2019). Recovering iron from iron ore tailings and preparing concrete composite admixtures. Minerals, 9(4), 232. https://doi.org/10.1080/14680629.2013.868820 